\title{
Field work on the Nagssugtoqidian boundary north of Angmagssalik and Tertiary igneous rocks of Kialineq and Kap Gustav Holm, East Greenland
}

\author{
John S. Myers, Håkon Austrheim, Robin C. O. Gill, Barry E. Gorman and \\ David C. Rex
}

Work was carried out from the 80 ton cutter Tycho Brahe using $16 \mathrm{ft}$ inflatable rubber dinghies between 24th July and 31st August 1978. In addition, the Nagssugtoqidian boundary was mapped westwards from Kangerdlugssuatsiaq to the inland ice cap by Bell 204 helicopter and part of the Kialineq region was mapped from a Piper Navajo aircraft (fig. 28).

The Nagssugtoqidian boundary was examined on the north shore of Kangerdlugssuatsiaq and a section through the northern part of the Nagssugtoqidian mobile belt was mapped along the shores of the upper part of Sermilik by rubber dinghy. Part of the Angmagssalik charnockite complex was examined in detail around Angmagssalik and Kap Dan. The Tertiary plutonic centres of Kialineq and Kap Gustav Holm were mapped in detail as well as the coastal dyke swarm in these regions, and samples were collected from all the main plutonic units for petrology and isotope studies.

\section{Nagssugtoqidian boundary}

The northern boundary of the Nagssugtoqidian mobile belt (fig. 28) is a major zone of complex shear zones, basic dyke intrusion, and retrogression of Archaean granulite facies to amphibolite facies rocks. The retrograde metamorphism and intrusion of basic dykes are intimately associated with the deformation, Nag. 1, which occurred 2600-2400 m.y. ago. The boundary and other Nag. 1 structures are folded by Nag. 2 deformation, which occurred 1900-1700 m.y. ago, and the boundary is now vertical along Kangerdlugssuatsiaq but dips $40^{\circ}$ to the north near the inland ice cap. More details are given by Bridgwater \& Myers (in prep.).

A swarm of basic dykes, here called the Charcot Fjelde dykes, were intruded at a high angle to the Nagssugtoqidian mobile belt during Nag. 2 deformation (fig. 28). They cut across the Nag. 1 structures and Archaean gneisses to the north but are deformed by Nag. 2 . The structure of this dyke swarm resembles that of the Kangâmiut dyke swarm (Bridgwater et al., 1973) to the south of the Nagssugtoqidian mobile belt in West Greenland and within the southern part of the mobile belt, although the Charcot Fjelde dykes are much less numerous than the Kangâmiut dykes.

The section mapped across the northern part of the mobile belt in the upper part of Sermilik (fig. 28) shows that a steep regional Nag. 1 foliation is folded by Nag 2. Tectonic fabrics and gneissose layering are then progressively obliterated by coarse recrystallisation which increases in intensity southwards as the zone of the Angmagssalik charnockite is approached.

\section{Kialineq plutonic centre}

The Kialineq plutonic centre (fig. 28) was discovered by Wager (1934) in 1930 and briefly described by Deer (1976), Brown et al. (1977) and Bridgwater et al. (1978). It was partly 

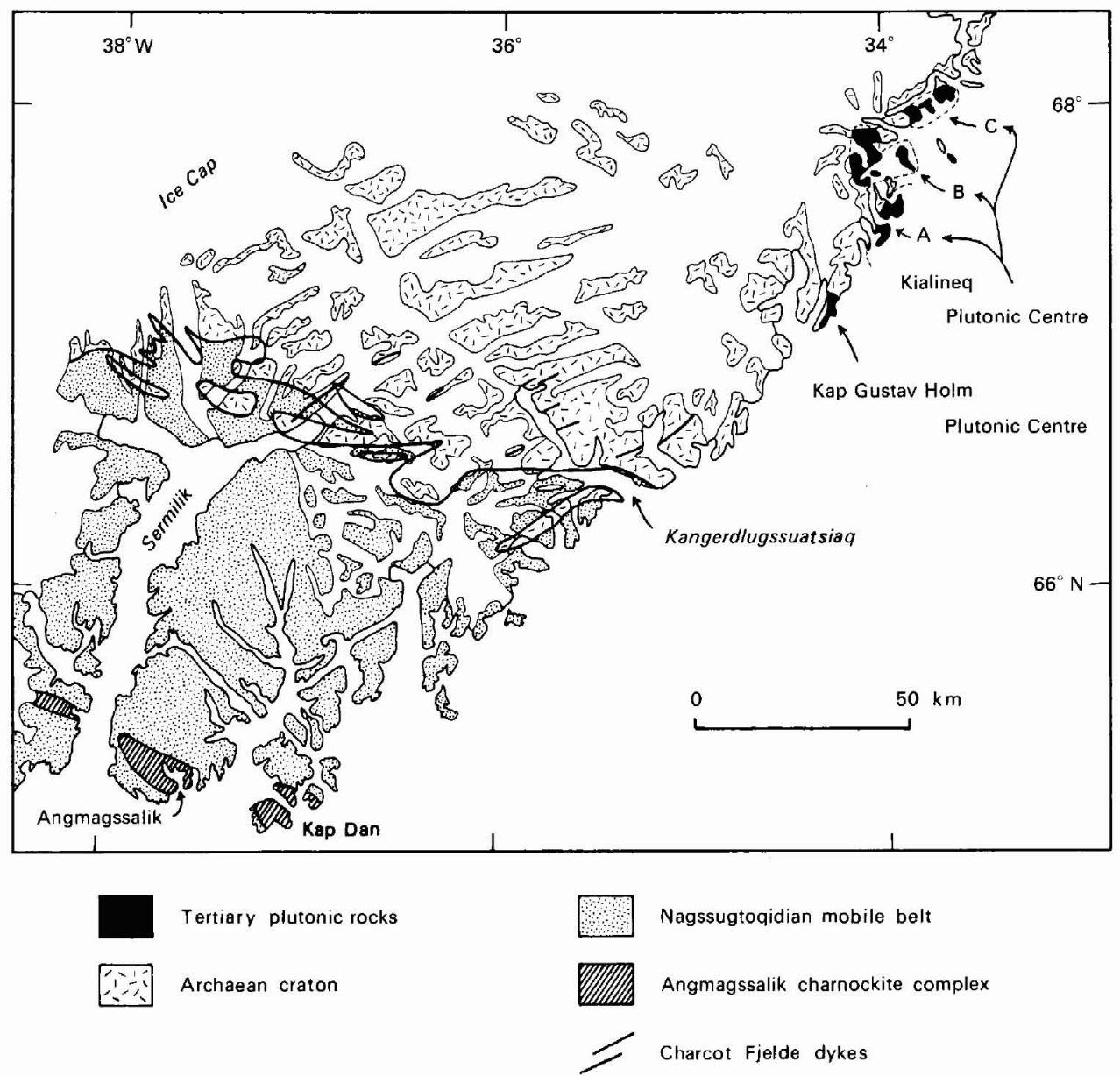

Fig. 28. Map showing the main geological features of East Greenland between latitudes $65^{\circ} 50^{\prime}$ and $68^{\circ} \mathrm{N}$.

mapped during reconnaissance surveys by Brown et al. (1977) in 1966 and by Bridgwater $e t$ al. (1978) in 1977. In 1978 the region was completely remapped in detail and the structure of the gabbros, diorites and syenites was determined for the first time.

In the south (fig. 28 , locality A), the Imilik gabbro cuts through the gneiss complex and a $200 \mathrm{~m}$ thick sequence of pillow lava, pillow lava breccia and tuff. The gabbro forms a funnel-shaped body within which the rocks accumulated in a number of pulses. The lower $3500 \mathrm{~m}$ of the Imilik intrusion consists of basic and ultrabasic rocks with a complex history of emplacement and synplutonic deformation. This is overlain by $6000 \mathrm{~m}$ of layered gabbro. The upper part of the intrusion is hidden beneath the sea but it is hoped to delineate this by an aeromagnetic survey in 1979. 
The central part of the Kialineq region (fig. 28 locality B) is dominated by a major body of diorite which is thoroughly fragmented by sheets of syenite containing pillowed intermediate dykes. A number of syenite ring dykes and then a major granite pluton were emplaced within the net-veined diorite.

To the north (fig. 28, locality C), syenite ring dykes and plutons with associated pillowed intermediate dykes were emplaced into the Precambrian gneiss complex.

\section{Kap Gustav Holm plutonic centre}

The Kap Gustav Holm plutonic centre (fig. 28) was discovered by Wager in 1930 and studied by $R$. Bøgvad in 1933 but the only description is a brief account by Wager (1934). GGU made a reconnaissance survey of the region in 1977 (Bridgwater et al., 1978) and mapped the region in detail in 1978. The plutonic centre comprises a major layered intrusion of gabbro, syenite plutons and ring dykes, a granite pluton and numerous basic and intermediate dykes. The gabbro was emplaced through the Precambrian gneiss complex into the base of the lava pile. A $300 \mathrm{~m}$ thick sequence of lavas are preserved, mainly pillow lava breccias and minor layers of tuff. The lavas overlie a $150 \mathrm{~m}$ thick sequence of sandstone which contains marine fossils in the top of the succession. Both sandstones and lavas are metamorphosed by the coastal dyke swarm and gabbro.

The gabbro is cut by three major units of syenite. An early hornblende syenite was followed by a major layered intrusion of syenite and this in turn by syenite ring dykes and a pluton of granite. Both the layered syenite and gabbro plutons contain a very large quantity of metamorphosed volcanic rafts deposited parallel with the igneous layering.

\section{Coastal dyke swarm}

The coastal dyke swarm was studied and sampled both across and along its length. The swarm can generally be divided in two on the basis of dip - with older dykes being tilted gently eastwards before being cut by younger steep dykes - but both the attitude and composition of the dykes vary along the length of the swarm. Some dykes persist for great distances along the main swarm but some groups of dykes form dense swarms of only local extent within the main dyke swarm.

\section{References}

Bridgwater, D., Davies, F. B., Gill, R. C. O., Gorman, B. E., Myers, J. S., Pedersen, S. \& Taylor, P. 1978: Precambrian and Tertiary geology between Kangerdlugssuaq and Angmagssalik, East Greenland. Rapp. Grønlands geol. Unders. 83, 17 pp.

Bridgwater, D., Escher, A. \& Watterson, J. 1973: Tectonic displacements and thermal activity in two contrasting Proterozoic mobile belts from Greenland. Phil. Trans. R. Soc. Lond. A 273, 513-533.

Bridgwater, D. \& Myers, J. S. in prep: Progress report on the Nagssugtoqidian of East Greenland. Rapp. Grønlands geol. Unders.

Brown, P. E., van Breeman, O., Noble, R. H. \& Macintyre, R. M. 1977: Mid-Tertiary igneous activity in East Greenland - the Kialineq complex. Contr. Miner. Petrol. 64, 109-122.

Deer, W. A. 1976: Tertiary igneous rocks between Scoresby Sund and Kap Gustav Holm, East Green- 
land. In Escher, A. \& Watt, W. S. (edit.) Geology of Greenland, 404-429. Copenhagen: Geol. Surv. Greenland.

Wager, L. R. 1934: Geological investigations in East Greenland, Part 1. General geology from Angmagsalik to Kap Dalton. Meddr Grønland 105, 2, 46 pp.

H. A.,

Geologisk Institutt,

Allegt. 41,

N-5014 Bergen,

Norway.

B. E. G.,

Department of Geology,

University of Western Ontario,

London, Ontario N6A 5B7,

Canada.
R. C. O. G., Department of Geology, Chelsea College, 271 King Street, London W6 $9 L Z$,

U. $K$.

D. C. R., Department of Earth Sciences, University of Leeds, Leeds LS2 9JT,

\section{Mapping of Tertiary basalts on the northern Blosseville Kyst, East Greenland}

\section{W. Stuart Watt and Margrethe Watt}

During the 1978 season work carried out by a helicopter-supported field team was concentrated in the region around Kap Dalton and Stenos Gletscher. The work formed a continuation of that carried out in 1975 in the coastal region between Kap Dalton and Steward $\varnothing$.

The main objectives were to link the stratigraphic sequence of the coastal region to that established for the Scoresby Sund area to the north and north-west. For this it was essential to gain a detailed knowledge of the inland behaviour of the coastal fault system.

\section{Lithostratigraphy}

Stratigraphic correlation in the region is based on 17 traverses totalling $8600 \mathrm{~m}$ of profile covering 1900-1950 m reckoned to be the total succession represented in the area.

For ease of correlation the lavas were divided into lithostratigraphic units based largely on phenocryst size and density combined with characteristic morphological features and colour of the flows.

The lower $650-700 \mathrm{~m}$ consists of sparsely or non-porphyritic flows weathering to a rich red-brown colour and commonly exceeding $50 \mathrm{~m}$ in thickness. Then, without noticable unconformity, a radical change takes place to a group of grey-weathering, often coarser, but usually quite thin flows. These are mixed porphyritic, often with large $(5-10 \mathrm{~cm})$ stellate aggregates of plagioclase and sometimes pyroxene, and non-porphyritic. Both types show marked pahoehoe features, sometimes separated by thin, occasionally fossiliferous, sedi- 